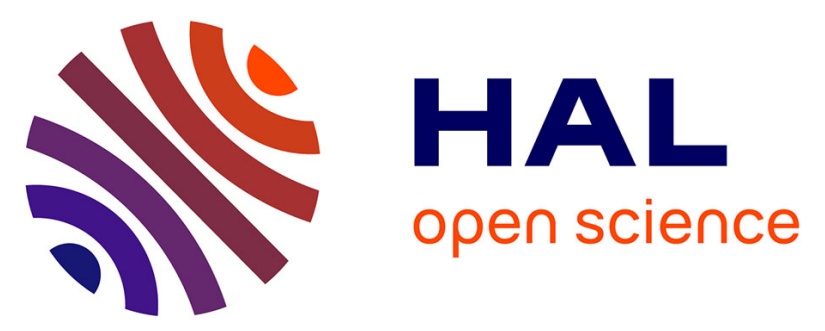

\title{
The FLK Zinj paleolandscape: Reconstruction of a 1.84 Ma wooded habitat in the FLK Zinj-AMK-PTK-DS archaeological complex, Middle Bed I (Olduvai Gorge, Tanzania)
}

\author{
Hector Arráiz, Doris Barboni, M. Gail Ashley, Audax Mabulla, Enrique \\ Baquedano, Manuel Dominguez-Rodrigo
}

\section{To cite this version:}

Hector Arráiz, Doris Barboni, M. Gail Ashley, Audax Mabulla, Enrique Baquedano, et al.. The FLK Zinj paleolandscape: Reconstruction of a 1.84 Ma wooded habitat in the FLK Zinj-AMK-PTK-DS archaeological complex, Middle Bed I (Olduvai Gorge, Tanzania). Palaeogeography, Palaeoclimatology, Palaeoecology, 2017, 488, pp.9 - 20. 10.1016/j.palaeo.2017.04.025 . hal-01531899

\author{
HAL Id: hal-01531899 \\ https://hal.science/hal-01531899
}

Submitted on 15 May 2018

HAL is a multi-disciplinary open access archive for the deposit and dissemination of scientific research documents, whether they are published or not. The documents may come from teaching and research institutions in France or abroad, or from public or private research centers.
L'archive ouverte pluridisciplinaire HAL, est destinée au dépôt et à la diffusion de documents scientifiques de niveau recherche, publiés ou non, émanant des établissements d'enseignement et de recherche français ou étrangers, des laboratoires publics ou privés. 


\title{
The FLK Zinj paleolandscape: reconstruction of a 1.84 Ma wooded habitat in the FLK Zinj-AMK-PTK-DS archaeological complex, Middle Bed I (Olduvai Gorge, Tanzania)
}

\author{
Arráiz H. ${ }^{1,2}$, Barboni D. ${ }^{2 *}$, Ashley G.M., Mabulla A. ${ }^{3}$, Baquedano E. ${ }^{5,6}$, \\ Domínguez-Rodrigo M. ${ }^{1,6}$
}

${ }^{1}$ Department of Prehistory, Complutense University of Madrid, Ciudad Universitaria s/n 28040 Madrid, Spain

${ }^{2}$ CEREGE, Aix-Marseille University, CNRS, IRD, Coll France, 13545 Aix-en-Provence cedex 4, France

${ }^{3}$ Earth and Planetary Sciences, Rutgers University, Piscataway, NJ, 08854-8066, USA

${ }^{4}$ Department of History and Archaeology, University of Dar es Salaam, Dar es Salaam, P.O. Box 35050, Tanzania

${ }^{5}$ Museo Arqueológico Regional de Madrid, Plaza de las Bernardas, Alcalá de Henares, Madrid, Spain

${ }^{6}$ IDEA (Instituto de Evolución en África), Covarrubias 36, 28010 Madrid, Spain.

*Corresponding author: barboni@cerege.fr

\begin{abstract}
A B S T R A C T
We have analyzed the phytolith content of 37 samples from the paleosol capped by Tuff IC dated 1.84 Ma within Middle Bed I at Olduvai Gorge, Tanzania. Samples were obtained from different trenches sampling an area of about 25 ha to document the paleovegetation associated with the abundant faunal remains and hominin artifacts in FLK, AMK, PTK and DS sites. The analysis reveals the abundance of globular granulate and forest indicator phytoliths (from 3\% to $86 \%$ relative to the total number of phytoliths in the assemblages) attributed to woody plants, and of short cell grass phytoliths (up to $22 \%$ ). The presence of palm phytoliths (up to 57\%) attests for meso-haline soils in the area in agreement with the presence of the saline/alkaline Olduvai paleolake and one (or more) groundwater discharge areas (freshwater springs and/or wetland). Phytoliths provide botanical evidence for a mixed paleovegetation dominated by forest and woodland with patches of open-spaces occupied by grasses, prior to the deposition of Tuff IC. The presence of fern phytoliths in some assemblages suggest shaded and humid habitat, which supports the presence of freshwater (watercourses or springs) that might have attracted hominins and other animals. Yet, we have found that our phytolith extractions (residues) also include micrometric zeolites (chabazite, clinoptilolite, phillipsite), which attest that the phytolith signal in the Zinj paleosols is certainly affected by dissolution. This study completes the spatial analysis of the area and reveals that the wooded area extends north, south, and west of FLK Zinj, with palm trees preferentially located in the periphery, like the Zinj, AMK, and DS sites. The phytolith-inferred distribution of plants does not support the hypothesis that topography was influential in the location of these sites, particularly given that trees and/or shrubs were dominant all over. Rather, it is the presence of freshwater ponds that seem to have been the attractive factor for hominins at this particular place and time.
\end{abstract}

Keywords: hominins, Paranthropus, paleovegetation, paleoenvironment, phytoliths, spring

\section{Introduction}

The East African Rift Valley is one of the most important areas to understand hominin evolution. A large number of hominin fossils have been discovered from south to north of the rift. At Olduvai Gorge (Tanzania) (Fig. 1), the holotype (OH5) of Paranthropus (Zinjanthropus) boisei was discovered in Level 22 (Zinj layer) of the FLK (Frida Leakey Korongo) site (Leakey, 1959). The hominin remains recovered during the excavations also included three more individuals of Homo habilis and P. boisei (OH6, OH35, OH44) 
(Day, 1976; Leakey et al., 1964; Tobias, 1991). When discovered, the site was considered as one of the first sites in which the co-occurrence of lithics and bone remains appeared functionally linked (Leakey, 1971). It was, and still is, the largest excavation of an anthropogenic site belonging to the Early Pleistocene. FLK Zinj is important for understanding early hominin behavior, the interpretation of which is still a matter of debate since Leakey (1971) suggested that the site was a "living floor". The abundance of skull and limb bones has been interpreted, so far, in two different ways (Domínguez-Rodrigo et al., 2007): a) hominins carried selected parts from fleshed carcasses to the site, and hence were most likely hunters (Bunn and Kroll, 1986; Domínguez- Rodrigo, 2002; DomínguezRodrigo and Pickering, 2003; DomínguezRodrigo, 1997; Oliver, 1994; Rose and Marshall, 1996); b) hominins transported selected skeletal parts from partially defleshed carcasses (Blumenschine, 1995; Capaldo, 1997), or completely defleshed carcasses, which implied the scavenging of brain and marrow-bearing long limb bones from prey found at felid kills (Blumenschine, 1995, 1991). The former interpretation is currently widely supported by taphonomic research (e.g. Domínguez-Rodrigo et al., 2014; DomínguezRodrigo, 2015). These interpretations grant different functionality to sites: a redundant transport of food surplus to the same location would promote food-sharing and central-place provisioning behaviors. The repeated transport of defleshed scavenged remains to the same spot would only be feasible if such location acted as a refuge (e.g., Blumenschine, 1991; Blumenschine et al., 1994). Earlier interpretations of the ecological context of FLK Zinj placed it in the middle of a barren lacustrine floodplain (Cole, 1967; Blumenschine and Masao, 1991). This was incompatible with the site having been a central-place spot or a refuge.

Earliest paleovegetation inferences, using pollen and stable carbon isotope studies, placed Olduvai Gorge Pleistocene sites in a grass-dominated landscape (Bonnefille, 1984, Cerling and Hay, 1986). Bovid ecomorphology later showed a significant proportion of intermediate and closed habitats (Bishop, 1994; Kappelman et al., 1997; Plummer and Bishop, 1994). Phytolith analyses of samples from FLK Zinj level 22 and contemporaneous paleosols in surrounding areas $(\sim 2$ ha) reconstructed a densely wooded environment near a freshwater spring (Ashley et al., 2010a). $\delta^{13} \mathrm{C}$ values for sedimentary leaf lipids and total organic carbon also indicated recurrent ecosystem variations, where open $\mathrm{C}_{4}$ grasslands abruptly transitioned to closed $\mathrm{C}_{3}$ forests within several hundreds to thousands of years (Magill et al. 2013a) in response to varying precipitation (Magill et al., 2013b). More recently, plant biomarkers from the Zinj level confirmed the presence of a dense forest patch with sedges and shadeloving ferns near the freshwater source at FLK $\mathrm{NN}$ and more open vegetation with $\mathrm{C}_{4}$ grasses at FLK S (Magill et al., 2016).

Subsequent research south of FLK Zinj suggested the presence of a river channel and a wetland 50 to $200 \mathrm{~m}$ southeast of FLK Zinj site (Blumenschine et al., 2012). Geoarchaeological and geometrically corrected reconstruction of the $1.84 \mathrm{Ma}$ FLK Zinj paleolandscape provides a different interpretation with water supplies coming from the south as low-energy watercourses (Uribelarrea et al., 2014). Further field research by the Olduvai Paleoanthropology and Paleoecology Project (TOPPP) in this southern area, lead to the discovery in 2012 of new archaeological sites in the same stratigraphic position as FLK Zinj level 22: PTK (Phillip Tobias Korongo), AMK (Amin Mturi Korongo) and DS (David's site) (Domínguez-Rodrigo et al., 2015; Uribelarrea et al., 2014), as well as to the discovery of a new tufa carbonate in the locality named PTK S (Driese and Ashley, 2015) (Fig. 1C).

In order to better interpret this large portion of the FLK Zinj paleolandscape and to analyze the influence of paleovegetation structure on human behavior, we present here the phytolith content of samples taken at FLK Zinj, AMK, PTK and DS on the same paleosol surfaces, as well as on an extensive set of trenches opened along the landscape in between these sites. To date, this is the most extensive collection of samples carried out to characterize the paleovegetation of the FLK Zinj paleolandscape.

\section{Material and Methods}

The main sequence studied at the type geo-locality of FLK Zinj is bracketed between Tuffs IB and IC (Fig. 2), which are easily recognizable and can be traced from FLK NN, to the south at PTK and AMK, and even to the 
east near the KK fault (Uribelarrea et al., 2014) (Fig. 1C). Tuff IB is an ash-fall tuff dated $1.848 \pm 0.003 \mathrm{Ma}$. It is mineralogically distinct from Tuff IC, but both tuffs yield indistinguishable argon-argon ages of $1.848 \pm$ $0.008 \mathrm{Ma}$ and $1.848 \pm 0.003 \mathrm{Ma}$ (Deino, 2012). Hence, sediments and paleosols between tuffs IB and IC were likely deposited within a time interval of 0.011 Ma (Magill et al. 2016). Between Tuffs IB and IC there is a clayey tuff/tuffaceous clay formed primarily of clay and a variable proportion of ashes, silt, and fine sand. Above this clayey tuff/tuffaceous clay, there is a laminated and reworked tuff called Chapati Tuff (CHT). Above CHT, up to Tuff IC is the "Zinj clay" stratigraphic unit that includes the archaeological Level 22 at FLK Zinj and Level 1 at FLKNN (Uribelarrea et al., 2014). The "Zinj clay" unit is characterized by two distinct clay types, and sharp lateral and vertical facies changes (Fig. 2B and 2C) (Driese and Ashley, 2015). The green waxy clay type with vertic (shrink-swell) features typical of Vertisols is most common in the study area, while the siliceous earthy clay type is found in some areas only, such as at PTK in some trenches only, at AMK locally in the east of the excavation site, and sporadically at DS.

AMK and PTK sites are located $500 \mathrm{~m}$ south of FLK Zinj site and comprise three archaeological levels, two of which are below Tuff IC, one of them being on the same paleosurface as Level 22 from FLK Zinj. PTK's third archaeological level underlies the Zinj clay, and occurs within the Chapati Tuff layer. In PTK, a modern hand phalanx belonging to an indeterminate modern-looking and fully terrestrial species was discovered, indicating the sympatric co-existence of at least three different types of hominins during Bed I times (Domínguez-Rodrigo et al., 2015). Recent archaeological work at FLK Zinj and at contemporaneous sites PTK, AMK, and DS, has uncovered a minimum of two depositional periods with clear sedimentary hiatus in between in the formation of the archaeological record of the FLK Zinj clay stratum (Domínguez-Rodrigo et al., 2010, Uribelarrea et al., 2014). The reconstruction of the paleolandscape targeted in the present analysis focuses on the uppermost level coinciding with the archaeological Level 22 at locality FLK Zinj, Level 1 at locality FLK NN, and Level 1 at AMK, which are collectively referred here as the Zinj clay stratum. This is also where most samples from previous paleobotanical reconstructions of the paleolandscape north of the site were obtained (Ashley et al., 2010). Phytolith data from Ashley et al. 2010 (10 samples) and from this study (27 new samples) are presented together here (Table 1).

Samples were collected directly below Tuff IC to ensure contemporaneity of phytolith assemblages. Each sample is composed of 3-5 sub-samples collected less than $50 \mathrm{~cm}$ apart, 0 $2 \mathrm{~cm}$ under Tuff IC. This sampling procedure ensures the identification of the vegetation pattern existing in the Zinj paleolandscape immediately prior to the deposition of Tuff IC at about $1.84 \mathrm{Ma}$ (Deino, 2012). Different samples were sometimes collected very close by because of lateral facies change such as at PTK in Trench 10/2013 (samples DB14-11 and -09) and in Trench 22/2014 (samples DB14-46 to -48) (Fig. 2C) (Table 1). The surface covered by the sampling is approximately 900 $\mathrm{m}$ from west to east and $600 \mathrm{~m}$ from north to south (Fig. 1C). Some samples were also collected vertically, in stratigraphy, up to 50 $\mathrm{cm}$ below Tuff IC, to study changes in vegetation over time. This was the case at FLK Zinj locality (samples DB12-67 to -69 in Trench FLK-03, and GA-Old-113-07 and -11407 in Trench FLK-T4).

The Zinj clay overlies Chapati Tuff (CHT) and is covered by Tuff IC (Fig. 2). Samples for phytolith analysis were collected in this clay deposit that is generally olive (5 Y 4/2), waxy, with well-developed paleosol structures (e.g. prismatic to subangular blocky peds with slickenside planes, more or less abundant rhizoliths and carbonate nodules) and which corresponds to a paleo-Vertisol (Driese and Ashley, 2015). This waxy clay deposits likely result from lake-margin sedimentation (in a saline lake) during times of higher precipitation $(\sim 700 \mathrm{~mm} / \mathrm{yr}$ : Magill et al., $2013 b$ ), and consequently lake-level highstands. During times of lower precipitation ( $\sim 250 \mathrm{~mm} / \mathrm{yr}$ : Magill et al., 2013b) and consequently lake-levels low-stands, soils developed from these exposed sediments. At PTK (Trenches 10/2013 and 22/2014), however, there is a sharp lateral facies change within $<1.5 \mathrm{~m}$ (Fig. 2B and 2C). Two types of deposits co-occur: the waxy-olive-clay (paleoVertisol) and a light gray (5Y 7/2) siliceous earthy clay without paleosol structures that is enriched in opaline silica (silicified plant remains, phytoliths, diatoms). Detailed 
micromorphological and whole-rock geochemical analyses conducted at PTK (Fig. 2B) indicate that the siliceous earthy clay (profile PTK B) developed under high ambient soil moisture, likely under the local influence of fault-controlled freshwater springs (Driese and Ashley, 2015). Interestingly, in the Zinj stratum overlaid by Tuff IC, siliceous earthy clay occurs in the center of our study area (Fig. 5).

For phytolith analyses dry sediments $(6-8 \mathrm{~g})$ were treated with pure $\mathrm{HCl}(33 \%)$ for $1-2 \mathrm{~h}$ to remove carbonates, and then with $\mathrm{H}_{2} \mathrm{O}_{2}$ at $80^{\circ} \mathrm{C}$ to remove organic matter. Clays were deflocculated using a solution of sodium hexametaphosphate $\left(\mathrm{NaPO}_{3}\right)_{6}$ buffered at $\mathrm{pH} 7$, and removed by decantation. Separation of phytoliths from heavy minerals was made using a $\mathrm{ZnBr}_{2}-\mathrm{HCl}$ heavy liquid set at $\mathrm{d}=2.3$ g. $\mathrm{cm}^{-3}$. The residue was mounted in benzyl benzoate. Slides were sealed with paraffin. Counting and phytolith identifications were carried out at magnification $\times 400$, and 150 to 350 phytoliths were counted per sample. Phytolith descriptions follow the international code for phytolith nomenclature (Madella et al., 2005). Phytoliths were classified according to their morphology and size, and compared against photographs and descriptions from previous work (Arraiz, 2016; Albert et al., 2016; Barboni et al., 2010; Collura and Neumann, 2016; Eichhorn et al., 2010; Garnier et al., 2012; Mercader et al., 2009; Novello et al., 2012; Piperno, 1997, 1998; Ollendorf, 1992; Strömberg, 2003). Phytoliths were subsequently grouped according to their most probable botanical origin (Appendix A). The non-botanical Forest Indicator (FI) category including silica bodies likely to occur in woody dicotyledons according to e.g. Runge (1999), Stromberg (2004, 2003, 2002), and Collura and Neumann (2016) was used as in previous phytolith studies at Olduvai (e.g., Ashley et al., 2010a, 2010b; Barboni et al., 2010). A selection of micrographs is shown in Fig. 3. Restionaceae produce a variety of discoidal phytoliths (diameter: 5-25 $\mu \mathrm{m}$, Cordova, 2013) that are hardly distinguishable from those produced by woody plants (Esteban et al., 2016). Phytoliths categorized as Glo10-11-12 can be mistaken with some globular regulate phytoliths found in Restionaceae, but none exhibit the spiraling decoration or the double ring on the edges, common in Restionaceae. Diagnostic Restionaceae morphotypes, such as the so-called boomerang and paddle types (Cordova and Avery, 2017) were also not observed in our samples. In our assemblages, most of the globular phytoliths attributed to FI are in the category Glo13, undoubtedly attributed to wood/bark tissues (Collura and Neumann, 2016). We attributed these globular phytoliths to FI considering that no other diagnostic phytoliths of Restionaceae (Cordova, 2013, Cordova and Avery, 2017) were found. In addition, our approach was conservative about attributions (as seen in the large percentages of non-diagnostic phytoliths). We consider that the main source of globular phytoliths in our assemblages was woody dicots.

Detailed composition of the phytolith assemblages is given in Figure 4. Pie diagrams used for interpreting vegetation patterns in the paleo-space (Fig. 5) and through time (Fig. 6) show different percentages because nondiagnostic and unknown phytolith types have been excluded to ease interpretations.

\section{Results}

In the paleosol samples analyzed here from the Zinj complex we observed 96 different phytolith morphotypes (Appendix A). Most could be recognized and attributed to a possible botanical producer group/signal. Nondiagnostic phytoliths, mainly within the Elongate and Blocky categories that are ubiquitous or that, to date, cannot be attributed to any specific taxon, however, represent a high proportion in all samples (up to $49 \%$ of the total phytolith assemblage, $\mu=21 \% \pm 12 \%$ ) (Fig. 4). In the FI category, globular decorated phytoliths represent up to $64 \%(\mu=26 \% \pm$ $19 \%$ ) and the other FI phytoliths (including some blocky, plates, and silicified dicot tissues) may also represent up to $60 \%(\mu=27 \% \pm 17 \%)$ (Fig. 4). Some globular bodies, vaguely pyramidal or tuberculate (see Appendix A for details) that we tentatively attributed to Marantaceae/Costaceae are also found abundant, particularly in FLK N and FLK Zinj localities. Globular echinate phytoliths of the Palm category occur in several samples with percentages of about $5-10 \%$ except in three samples (GA-Old-114-07 at FLK Zinj, MDR14-2 at DS, and DB14-27C at AMK) where they account for $20->40 \%$. Grass silica short cell phytoliths (GSSCs) are weakly represented $(\mu=8 \% \pm 6 \%$, range $0-23 \%)$ and 
include mainly trapeziform shortcells, rondels and bilobates (Fig. 4). Silicified bulliform cells attributable to grasses and sedges occur in many samples in low percentages, probably also reflecting the fact that grasses were rare in the paleovegetation. Cyperaceae (sedges) hexagonal platelets (so-called hat-shaped phytoliths, Fig. 3G), account for 2-3\% in several samples. Blocky facetted phytoliths that we have attributed to Pteridophytes (ferns) are present in 12 samples in low frequencies $(<$ $7 \%, \mu=1 \% \pm 2 \%$ ).

In samples from the paleosurface underlying Tuff IC, pie diagrams with diagnostic phytoliths show that Forest Indicators (FI) is the most represented category, followed by Grasses and Palms (Fig. 5). Grass/sedge phytoliths are also well represented, particularly at FLK Zinj, FLK S, DS and PTK. Yet, values of the $\mathrm{D} / \mathrm{P}^{\circ}$ index (the ratio of globular granulate plus globular echinate over the sum of grass silica short cells, Bremond et al., 2005) are all largely $>1$ and therefore indicate forest. No phytolith counts of GSSCs plus globular granulate + globular echinate were $>200$ so comparison of $\mathrm{D} / \mathrm{P}^{\circ}$ values between sites is inappropriate (Stromberg, 2009). Samples from PTK and DS sites show similar phytolith assemblages to those from FLK Zinj: Forest indicator phytoliths represent the strongest signal (37\%$75 \%)$ followed by Palms (8-16\%) and Grasses/Sedges (8-18\%). The PTK samples are richer in GSSCs than the northern samples. In the Zinj stratum underlying Tuff IC, phytolith data indicate more palms and grasses in the south, and more FI and Grass/Sedges in the northern part of the paleo-surface (Fig. 5). FLK Zinj, PTK, and DS archaeological sites are characterized by almost similar proportions of FI $>$ Palms $>$ Grasses, while AMK is dominated by Palms. The presence of palms in most assemblages indicates that they were regular component of the forested habitat, but the relative abundance of globular echinate phytoliths is not linearly correlated with the abundance of palms in the vegetation (Albert et al., 2015). High percentages of globular echinate phytoliths occur in palm swamp ( $\sim 60 \%$, Bremond et al., 2005) but also in the Acacia-Hyphaene groves near lakes Manyara and Eyasi, (Arráiz, 2016; Albert et al., 2015) and near the Bonar and Banagi rivers in the Serengeti Plains (Albert et al., 2015), where percentages of globular echinate phytoliths in surface soils represent $\sim 10 \%$. Despite the low presence of fern phytoliths in the assemblages, their remains were found in all sites and their presence suggests shady and wet habitat (Kamau, 2012). The presence of ferns in samples from FLK Zinj is also attested by the presence of specific biomarkers (Magill et al., 2016).

The analysis of samples collected vertically through the stratigraphic succession shows a clear pattern according to the lithology: palm phytoliths only occur in the waxy (vertisol) clays, and are absent in the siliceous earthy clays (Fig. 6). The three samples collected from FLK-T4 at $0 \mathrm{~cm}, 8 \mathrm{~cm}$, and $12 \mathrm{~cm}$ below IC in green waxy clay exhibit phytolith assemblages with different proportions of FI, Marantaceae/Costaceae, Grass, and Palm phytoliths, but Palms are always present from bottom to top. In the nearby trench FLK-T3 and in trench PTK B 10/2013 the same pattern occurs: palm phytoliths are only found in the waxy vertisol clays. Laterally, differences in the lithology (waxy clays versus siliceous earthy clays) are also visible over the paleosurface directly underlying Tuff IC. Siliceous earthy clay occurs preferentially in the center of the study area, and waxy (vertisol) clay in the periphery. Interestingly Palm phytoliths are rare to absent in siliceous earthy clay samples. Palms are therefore preferentially present in the periphery, likely where soil moisture was less important. Yet, we note one exception: DB1427C at AMK from siliceous clay has abundant Palm phytoliths (Fig. 5).

Heterogeneity in the phytolith assemblages sometimes occurs over short distances. At AMK for example, Palm phytoliths represent $57 \%$ in sample DB14-27C, and just a mere $2 \%$ in DB14-29 collected $<10$ $\mathrm{m}$ away (Fig. 5). On the contrary, the DS samples have a homogeneous signal dominated by FI and palm phytoliths. At PTK, samples DB14-46, 47, and 48, sampled in waxy clay under Tuff IC over one meter-long transect (Fig. 2C), do not show changes in phytolith composition over short spatial distance, despite visible facies change and increasing carbonate content (as suspected by observing increasing fizzing reaction to $\mathrm{HCl}$ from sample DB14-46 to DB14-48). These PTK samples are dominated by FI phytoliths (63-78\%). Grasses/sedges phytoliths represent $6-9 \%$, and palm phytoliths are present in DB14-46 (2\%) 
and DB14-47 (3\%), but not in the more carbonate-rich DB14-48.

\section{Discussion}

The results obtained for the new samples analyzed in the present study, for the area south of FLK Zinj are similar to those obtained by Ashley et al. (2010a) in the north of the site, who provided evidence for a freshwater spring and closed wooded vegetation in FLK NN, using $\delta^{13} \mathrm{C}$ and $\delta^{18} \mathrm{O}$ isotopes as well as phytoliths. In Ashley et al. (2010a) the number of "other FI" is lower than in our samples. This implies that in our study area the presence of bushes, saplings or non woody dicotyledonous plants could be more important than in the paleovegetation reconstruction of FLK NN (Ashley et al., $2010 \mathrm{~b}$ ), or that different woody plants occurred in this southern area (Collura and Neumann, 2016). The FLK Zinj area was likely covered by closed wooded vegetation before the deposition of Tuff IC, which is a suitable habitat for ferns. The presence of fern phytoliths in the southern part of the studied area may reflect the presence of watercourses (Uribelarrea et al., 2014) or springs (Driese and Ashley, 2015). Fern remains were not observed in the FLK Zinj samples previously analyzed (Ashley et al., 2010a), plausibly because phytoliths in ferns have been poorly documented (Mazumdar, 2001) until now (Arraiz, 2016).

In our samples, grass phytoliths (GSSCs) are found systematically with very low abundance and we note that one of the best-represented morphologies is the trapeziform shortcell (also called trapezoid) (GSSC42 and 46). This contrasts with the results obtained in many surface soil samples from tropical Africa where these phytoliths rarely occur in the assemblages (e.g., Barboni et al., 2007; Barboni and Bremond, 2009; Bremond et al., 2008; Novello et al., 2012; Runge, 1999). However, trapeziform shortcells occurs in $32 \%$ of fynbos grass species, and in $24-55 \%$ of montane grasslands grasses (Rossouw, 2009). Cordova (2012) found that they are common in $\mathrm{C}_{3}$ temperate grasses from South Africa, and are associated with winter precipitation, but only weakly. Rossow and Scott (2011) show that Trapeziform square phytoliths are discriminant factors for grasses from cool growing temperature and permanent moisture habitats. Three hypotheses can explain these relatively high levels of trapeziform shortcells: 1) there were some cooler, humid and shady spots, caused by spring water and associated vegetation, 2) trapeziform shortcells are more resistant to dissolution than other GSSCs, and 3) at the moment of deposition of these phytolith assemblages, the Ngorongoro volcano crater had a higher altitude (Hay, 1976), triggering cooler temperatures favorable to the growth of trapeziform shortcell phytoliths producers like Pooideae grasses .

Another explanation may be that we have misidentified trapeziform short cell phytoliths with small crystals of chabazite (Fig. 7E). Misidentification could also have occurred for some globular types attributed to Marantaceae/Costaceae, as zeolitization creates neat ridges (crystal edges) that make globular phytoliths resemble druses (see Fig. 7D). SEM observations confirmed the presence of minerals in our phytolith preparations, but the presence of chabazite, clinoptilolite and philipsite of the zeolite group was confirmed by $\mathrm{x}$-ray analyses. These zeolites have a specific gravity of 2.0-2.2 $\mathrm{g} . \mathrm{cm}^{-3}$ like phytoliths, and their elemental composition with $\mathrm{Si}$ and $\mathrm{O}$ is also very close to biogenic silica. Also, adding to the confusion, despite the fact that zeolites crystallize, their refraction index is low (Tschernich, 1992). Zeolites are known as the common end product of ash alteration under alkaline conditions (Hay 1976). Here we see that zeolite crystals also use phytoliths as nucleus to grow (Fig. 7A). In our samples we observe that the abundance of diagnostic phytoliths is negatively correlated with the abundance of zeolites, but that green waxy clays are likely to better preserve phytoliths than the so-called siliceous earthy clay (Fig. 8). Interestingly, we also observe that the greater the abundance of zeolites, the greater the abundance of unidentified, damaged and dubious morphotypes in siliceous earthy clay samples but not in the waxy clay samples (Fig. 8). Dissolution is therefore harsher on phytoliths in the siliceous earthy clay than in the waxy clays. According to Driese and Ashley (2015), the waxy clays at FLK, PTK and E4 are typical for paleo-Vertisols, which underwent frequent drying-wetting. The earthy siliceous clays were not subjected to as much wetting and drying as the waxy clays because they contain less clay, are porous and have more silica that enhances zeolite formation 
(Hay, 1971, 1976; Deocampo and Ashley, 1999; Ashley and Driese, 2000; Liutkus and Ashley, 2003). Earthy siliceous clays are, therefore, considered as proxy evidence for frequently/permanently moist and wet soils. At AMK, more than $30 \%$ of the remains recovered from Level 1 (directly underlying Tuff IC) "show some king of biochemical alteration related to the presence of root etching of associated bacteria, typical of humid environments" (Aramendi et al. 2017, this volume). Preserved bones also exhibit carbonate concretions, which usually occur due to the presence of water. In addition, at AMK the bone assemblage configuration indicates that flowing water played a small role and did not alter the bone orientation pattern significantly. This carnivore site was therefore located in an area very likely under the influence of a groundwater discharge area (spring) where high groundwater table maintained the soils wet and bacterial activity that modified the bones. Bone assemblages and taphonomy at AMK (Aramendi et al., 2017, this volume) and paleosols geochemical studies in the nearby site of PTK (Driese and Ashley, 2015) converge to the same conclusion that the area south of FLK Zinj had high soil moisture, likely supplemented by seepage addition from nearby springs. Tufa carbonates do indeed occur at PTK S and FLK NN within the same stratigraphic unit as the archaeological/paleontological levels under our interest here at FLK Zinj (Level 22), AMK (Level 1), PTK (Level 1), and DS (Level 1) (Driese and Ashley, 2015). Both tufas are found underlying Tuff IC and about $2-3 \mathrm{~cm}$ of waxy clay. If a sedimentation rate of 0.1 $\mathrm{mm} . \mathrm{yr}^{-1}$ for paleosol formation is considered (Ashley et al., 2014), then the 2-3 cm of waxy clay represents about 200-300 yr of lacustrine sedimentation above the tufas. Waxy clay is the dominant lithology throughout the Zinj stratum except in the central area where clays are of the siliceous earthy type (Fig. 5). In the central area, siliceous earthy clay directly underlies Tuff IC. Vertisols are therefore surrounding a spring-fed area of siliceous earthy clay. Phytolith assemblages do not show striking differences according to the clay types. Yet, palm phytoliths are most abundant in the periphery, not the central area. It is also in the periphery, where the abundance of palms is the highest that the paleontological sites of FLK Zinj, AMK, and DS have been found. The central area has highest Forest Indicator and grass/sedges. It was probably the wettest part of the Zinj paleolandscape. It is still not clear, though, what is the geological evidence for springs contemporaneous to the Zinj stratum: the tufa carbonates found $2-3 \mathrm{~cm}$ below waxy clay at FLK NN and PTK S, or the siliceous earthy clay directly underlying Tuff IC in the central area?

Zeolites indicate alkaline environments. Paleosol studies of the Zinj surface indicate moderate to strongly alkaline soil $\mathrm{pH}$ of 7.9-8.5, which certainly has contributed to phytolith dissolution (Driese and Ashley, 2015). At alkaline pH, phytoliths have high rates of dissolution (Fraysse et al., 2006). Morphotype three-dimensional shape and surface decoration could therefore be lost (Cabanes et al., 2011; Cabanes and ShahackGross, 2015). Taphonomical processes, however, affect phytolith morphotypes differently, such as certain morphologies are more stable than others. For example, globular granulate are better preserved than grass silica short cells in the sense that they retain enough of their morphological shape to be recognized as globular bodies, while grass silica short cells such as bilobate are likely to considered "unidentifiable" after dissolution has started to modify the 3D shape (Cabanes et al., 2011). Despite this, the conservation of some GSSC phytoliths and, above all, the preservation of hexagonal platelets (hat-shaped) phytoliths of Cyperaceae (sedges), rarely preserved even in surface soil samples (Novello et al., 2012), suggest that paleovegetation patterns, rather than partial dissolution of phytoliths due to taphonomical processes, are responsible for the phytolith assemblages obtained here. We note, however, that using organic biomarkers Magill et al. (2016) obtained a strong signal for $\mathrm{C}_{4}$ grasses in the central area (between FLK Zinj and PTK), which is not corroborated by the abundance of e.g. saddle, rondel, or bilobate grass silica short cell phytoliths. Organic biomarkers also trace the presence of Pteridophytes in FLK-NN, but fern phytoliths are found also between FLK Zinj and PTK, in DS and AMK. To date, we don't know what could explain such discrepancy between phytolith and the organic markers.During the deposition times, the study area was located within a surrounding paleolandscape characterized by open spaces dominated by grasses and sedges with scarce presence of 
arboreal plants (Bonnefille, 1984). Our results support the importance of zonal variations in water supplies to create the Olduvai local vegetation, different from the large-scale paleolandscape vegetation. It seems that in the northern area (FLK N, FLK NN), the presence of spring-associated woodlands was recurrent (Ashley et al., 2010a, 2010b; Barboni et al., 2010; Barboni, 2014). This patched vegetation of groundwater woodlands mixed with wooded grasslands is currently common around lakes Manyara and Eyasi, which are potential modern analogues of paleolake Olduvai (Barboni, 2014), and near several rivers in the Serengeti Plains (Albert et al., 2015).

The results presented here show an extension of the area covered by wooded vegetation to the south of FLK Zinj, including the southern part of FLK Zinj, AMK, PTK and DS, which is relevant to understanding hominin behavior. In the southern part of FLK Zinj, the lack of archaeological remains does not suggest a hominin occupation, but PTK and DS exhibit a dense accumulation of cut-marked faunal remains associated with large stone tool assemblages (Arriaza and Domínguez-Rodrigo, 2016) in the same clay stratum and paleosurface deposit underlying Tuff IC, which contains FLK Zinj. AMK site is interpreted as a carnivore palimpsest with very little human influence (Aramendi et al., 2017, this volume). In PTK, the earliest modern human-like hand bone was found (Domínguez-Rodrigo et al., 2015). The presence of these remains, along with the evidence of a paleovegetation similar to that previously described in FLK Zinj (Ashley et al., 2010a), suggests similar relationship between hominins, fauna and environment for the three sites FLK Zinj, PTK and DS. FLK Zinj is well known for the dense concentration of archaeological remains (Domínguez-Rodrigo et al., 2010a, 2010b; Leakey, 1971), and has been interpreted as a site with an anthropogenic origin, where lithic remains and bones processed by hominins are functionally-related (Domínguez-Rodrigo et al., 2007). A behavioral model has been proposed, in which hominins used the site to process animal carcasses in a central-place foraging behavior, and not only as refuge (e.g., Ashley et al., 2010a; Domínguez-Rodrigo et al., 2007). These areas were repeatedly occupied and hominins probably carried out a wide range of activities there (Bunn and Kroll, 1986). This model refuted the idea that hominins were attracted to these loci simply because they contained closed vegetation, for shade and refuge. According to Blumenschine et al. (2012), FLK Zinj was selected by hominins because of its topographic position as a peninsula surrounded by wetland and/or watercourses. Uribelarrea et al. (2014) by sampling a larger area showed that "the FLK Zinj-PTK strip was a topographically high plateform with no evidence of large rivers crossing it or high-energy processes affecting it". Hence, the FLK NN-FLK Zinj-AMKPTK-DS complex was likely situated on the same elevated platform overlooking the lower portion of the lacustrine floodplain, which therefore leads to think that topography was not influential in the location of the archaeological sites.

Our study shows that a wooded habitat was predominant, but with relatively more grass/sedges in the central area with siliceousspring-clay (hatched orange, Fig. 5), and more palms in the periphery with waxy-Vertisolsclay. Vegetation physiognomy thus exhibits some differences according to the lithology, and suggests that the central area had likely damp soils. Zinj, PTK, and DS anthropological sites, as well as the carnivore site of AMK are all located in close vicinity of this likely freshwater "pond", in its periphery. Palm trees and freshwater seem to have been determinant on the location of these sites (as suggested Ashley et al., 2010a; Barboni, 2014). The FLK NN-FLK Zinj-AMK-PTK-DS complex was likely an undulating surface, with very subtle topography and it appears that the center was slightly lower and periphery higher (supporting palms). The phytolith-inferred distribution of plants does not support the hypothesis that topography was influential in the location of these sites, particularly given that trees and/or shrubs were dominant all over. Rather, it is the presence of freshwater ponds that seem to have been the attractive factor. Other reasons, such as the presence of specific plant types, or preys attracted by the freshwater could also have been important factors in the selection of those places by hominins. The presence of a freshwater spring (north and potentially south of FLK Zinj, Ashley et al 2010, Driese and Ashley, 2015) and fluvial watercourses (potentially south of FLK Zinj, Uribellarea et al., 2014) served as sources of potable water and were attractive both to hominins and animals during dry periods. The profiles of 
bovid mortality found in FLK Zinj show that hominins could have acted as ambush predators (Bunn and Pickering, 2010), and that they may have had early access to intact carcasses (Pickering and Domínguez- Rodrigo, 2006). Despite the well traced relation between tools and cut-marked bones, the interpreted environment may have been also a source of plants for feeding purposes (Rose and Marshall, 1996), as suggested by the multiple purpose Oldowan tool kit containing cutting and hacking tools (Diez-Martín et al., 2010, 2015).

\section{Conclusions}

Our phytolith data of the "Zinj complex" (FLK N, FLK Zinj, AMK, PTK and DS sites) provides now a fairly complete reconstruction of a paleovegetation dominated by forest/woodland in which palms would have been a regular component at the time of deposition of Tuff IC 1.84 million years ago. Palms and grasses happen to be most abundant at the Zinj, AMK, PTK, and DS sites, i.e. in the periphery of the study area where Vertisols(waxy)-clay is the dominant lithology. In the center of the study area, where dominant lithology is siliceous earthy clay and zeolitized phytoliths are most abundant, the vegetation is characterized by woody plants and grasses/sedges, not palms. The center of the area therefore provides several evidences for a damp/wet zone with continuous fresh water, not very favorable to the semi-halophile palms. Interestingly, if siliceous earthy clay is spring clay, then when Tuff IC was deposited, the only spring area was very near AMK, PTK and DS, not in the Zinj locality or FLK-NN where there is waxy clay. The presence of ferns in the assemblages suggest shady and wet habitats, which is supported by the geological reconstruction of watercourses or groundwater discharge along a north-south fault between PTK and DS sites, and the likely presence of groundwater discharge area south of PTK. Our study also reevaluates previous paleoecological inferences. The presence of hominin remains and archaeological materials in PTK and DS suggest that hominins used the sites to process and consume animal carcasses, and that the reasons why those specific spots were selected for such activities is likely the presence of freshwater pond as all anthropological sites are distributed in its periphery.

\section{Acknowledgments}

We thank the Tanzanian Commission for Science and Technology (COSTECH), the Department of Antiquities and Ngorongoro Conservation Area Authority in the Ministry of Natural Resources and Tourism for permission to conduct research at Olduvai Gorge. We thank The Olduvai Paleoanthropology and Paleoecology Project (TOPPP) for leading and carrying out this project and supporting DB fieldwork. We also thank the Spanish Ministry of Economy and Competitiveness for funding HA research (HAR2013-45246-C3-1-P) and the Ministry of Culture for supporting HA travels to France through their Archaeology Abroad program. At CEREGE we thank D. Borschneck for $\mathrm{x}$-rays analyses and interpretations. We thank Carlos Cordova and an anonymous reviewer for helpful comments.

\section{References}

Albert, R.M., Bamford, M.K., Cabanes, D., 2009. Palaeoecological significance of palms at Olduvai Gorge, Tanzania, based on phytolith remains. Quaternary International 193, 41-48. doi:10.1016/j.quaint.2007.06.008

Albert, R.M., Bamford, M.K., Esteban, I., 2015. Reconstruction of ancient palm vegetation landscapes using a phytolith approach. Quaternary International 369, 5166. doi:10.1016/j.quaint.2014.06.067

Albert, R.M., Esteve, X., Portillo, M., Rodríguez-Cintas, A., Cabanes, D., Esteban, I., Hernández, F., 2016. Phytolith CoRe, Phytolith Reference Collection [WWW Document]. URL http://phytcore.org/ (accessed 2.1.16).

Aramendi, J., Uribelarrea, D., Arriaza, M.C., Arráiz, H., Barboni, D., Yravedra, J., Ortega, M.C., Gidna, A., Mabulla, A., Baquedano, E., others, 2017. The paleoecology and taphonomy of AMK (Bed I, Olduvai Gorge) and its contributions to the understanding of the "Zinj" paleolandscape. Palaeogeography, Palaeoclimatology, Palaeoecology.

Arráiz, H., 2016. Reconstrucción de la paleovegetación y uso de útiles líticos en el yacimiento de homínidos de la garganta de Olduvai (Tanzania) mediante el uso de microfósiles vegetales. Universidad Complutense de Madrid, Madrid.

Arriaza, M.C., Domínguez-Rodrigo, M., 2016. 
When felids and hominins ruled at Olduvai Gorge: A machine learning analysis of the skeletal profiles of the non-anthropogenic Bed I sites. Quaternary Science Reviews 139 , $43-52$. doi:http://dx.doi.org/10.1016/j.quascirev.20 16.03.005

Ashley, G.M., Barboni, D., DomínguezRodrigo, M., Bunn, H.T., Mabulla, A.Z.P., Diez-Martin, F., Barba, R., Baquedano, E., 2010a. A spring and wooded habitat at FLK Zinj and their relevance to origins of human behavior. Quaternary Research 74, 304314. doi:10.1016/j.yqres.2010.07.015

Ashley, G.M., Barboni, D., DomínguezRodrigo, M., Bunn, H.T., Mabulla, A.Z.P., Diez-Martin, F., Barba, R., Baquedano, E., 2010b. Paleoenvironmental and paleoecological reconstruction of a freshwater oasis in savannah grassland at FLK North, Olduvai Gorge, Tanzania. Quaternary Research 74, 333-343. doi:10.1016/j.yqres.2010.08.006

Ashley, G.M., Beverly, E.J., Sikes, N.E., Driese, S.G., 2014. Paleosol diversity in the Olduvai Basin, Tanzania: Effects of geomorphology, parent material, depositional environment, and groundwater on soil development. Quaternary International, (322-323): 66-77. doi:10.1016/j.quaint.2013.12.047

Ashley, G.M., Driese, S.G., 2000. Paleopedology and paleohydrology of a volcaniclastic paleosol interval: implications for early Pleistocene stratigraphy and paleoclimate record, Olduvai Gorge, Tanzania. Journal of Sedimentary Research 70, 1065-1080.

Barboni, D., Bremond, L., Bonnefille, R., 2007. Comparative study of modern phytolith assemblages from inter-tropical Africa. Palaeogeography Palaeoclimatology Palaeoecology 246, 454-470. doi:10.1016/j.palaeo.2006.10.012

Barboni, D., Bremond, L., 2009. Phytoliths of East African grasses: An assessment of their environmental and taxonomic significance based on floristic data. Review of Palaeobotany and Palynology 158, 29-41. doi:10.1016/j.revpalbo.2009.07.002

Barboni, D., 2014. Vegetation of Northern Tanzania during the Plio-Pleistocene: A synthesis of the paleobotanical evidences from Laetoli, Olduvai, and Peninj hominin sites. Quaternary International 322-323,
264-276. doi:10.1016/j.quaint.2014.01.016

Barboni, D., Ashley, G.M., DomínguezRodrigo, M., Bunn, H.T., Mabulla, A.Z.P., Baquedano, E., 2010. Phytoliths infer locally dense and heterogeneous paleovegetation at FLK North and surrounding localities during upper Bed I time, Olduvai Gorge, Tanzania. Quaternary Research 74, 344-354. doi:10.1016/j.yqres.2010.09.005

Blumenschine, R.J., 1995. Percussion marks, tooth marks, and experimental determinations of the timing of hominid and carnivore access to long bones at $\{\mathrm{FLK}\}$ Zinjanthropus, Olduvai Gorge, Tanzania. Journal of Human Evolution 29, 21-51. doi:http://dx.doi.org/10.1006/jhev.1995.104 6

Blumenschine, R.J., 1991. Hominid carnivory and foraging strategies, and the socioeconomic function of early archaeological sites. Philos Trans R Soc Lond B Biol Sci 334, 211-9-221. doi:10.1098/rstb.1991.0110

Blumenschine, R.J., Stanistreet, I.G., Njau, J.K., Bamford, M.K., Masao, F.T., Albert, R.M., Stollhofen, H., Andrews, P., Prassack, K.A., McHenry, L.J., Fernández-Jalvo, Y., Camilli, E.L., Ebert, J.I., 2012. Environments and hominin activities across the FLK Peninsula during Zinjanthropus times (1.84 Ma), Olduvai Gorge, Tanzania. Journal of Human Evolution 63, 364-383. doi:10.1016/j.jhevol.2011.10.001

Bonnefille, R., 1984. Palynological research at Olduvai Gorge, in: Lea, J.S., Link Powars, N., Swanson, W. (Eds.), . Washington, DC, pp. 227-243.

Bremond, L., Alexandre, A., Wooller, M.J., Hely, C., Williamson, D., Schafer, P.A., Majule, A., Guiot, J., 2008. Phytolith indices as proxies of grass subfamilies on East African tropical mountains. Global and Planetary Change 61, 209-224. doi:10.1016/j.gloplacha.2007.08.016

Bunn, H.T., Kroll, E.M., 1986. Systematic Butchery by Plio/Pleistocene Hominids at Olduvai Gorge, Tanzania. Current Anthropology 27, 431-452.

Bunn, H.T., Pickering, T.R., 2010. Bovid mortality profiles in paleoecological context falsify hypotheses of endurance runninghunting and passive scavenging by early Pleistocene hominins. Quaternary Research 74 , 395-404. 
Cabanes, D., Shahack-Gross, R., 2015. Understanding Fossil Phytolith Preservation: The Role of Partial Dissolution in Paleoecology and Archaeology. PLOS ONE 10, e0125532. doi:10.1371/journal.pone.0125532

Cabanes, D., Weiner, S., Shahack-Gross, R., 2011. Stability of phytoliths in the archaeological record: a dissolution study of modern and fossil phytoliths. Journal of Archaeological Science 38, 2480-2490. doi:10.1016/j.jas.2011.05.020

Capaldo, S.D., 1997. Experimental determinations of carcass processing by Plio-Pleistocene hominids and carnivores at FLK 22 (Zinjanthropus), Olduvai Gorge, Tanzania. Journal of Human Evolution 33, 555-597.

Cerling, T.E., Hay, R.L., 1986. An isotopic study of paleosol carbonates from Olduvai Gorge. Quaternary Research 25, 63-78.

Collura, L.V., Neumann, K., 2016. Wood and bark phytoliths of West African woody plants. Quaternary International. doi:10.1016/j.quaint.2015.12.070

Cordova, C., Avery, G., 2017 in press. African savanna elephants and their vegetation associations in the Cape Region, South Africa: Opal phytoliths from dental calculus on prehistoric, historic and reserve elephants. Quaternary International. doi:10.1016/j.quaint.2016.12.042

Day, M., 1976. Hominid postcranial material from Bed I, Olduvai Gorge, in: Isaacs, G.L., McCown, E.R. (Eds.), Human Origins: Louis Leakey and the East African Evidence. WA Benjamin Inc, Menlo Park,California, pp. 363-374.

Deocampo, D., Ashley, G., 1999. Siliceous islands in a carbonate sea: Modern and Pleistocene spring-fed wetlands in Ngorongoro Crater and Oldupai Gorge, Tanzania. Journal of Sedimentary Research 69, 974-979.

Deino, A.L., 2012. 40Ar/39Ar dating of Bed I, Olduvai Gorge, Tanzania, and the chronology of early Pleistocene climate change. Journal of Human Evolution 63, 251-273. doi:10.1016/j.jhevol.2012.05.004

Diez-Martin, F., Sanchez Yustos, P., Domínguez-Rodrigo, M., Mabulla, A.Z.P., Bunn, H.T., Ashley, G.M., Barba, R., Baquedano, E., 2010. New insights into hominin lithic activities at FLK North Bed I, Olduvai Gorge, Tanzania. Quaternary
Research 74, 376-387. doi:10.1016/j.yqres.2010.07.019

Diez-Martín, F., Sánchez Yustos, P., Uribelarrea, D., Baquedano, E., Mark, D.F., Mabulla, A., Fraile, C., Duque, J., Díaz, I., Pérez-González, A., Yravedra, J., Egeland, C.P., Organista, E., Domínguez-Rodrigo, M., 2015. The Origin of The Acheulean: The 1.7 Million-Year-Old Site of FLK West, Olduvai Gorge (Tanzania). Scientific Reports 5, 17839. doi:10.1038/srep 17839

Domínguez- Rodrigo, 2002. Hunting and Scavenging by Early Humans: The State of the Debate. Journal of World Prehistory 16, $1-54$.

Domínguez-Rodrigo, 1997. Meat-eating by early hominids at the FLK 22 Zinjanthropus site, Olduvai Gorge (Tanzania): an experimental approach using cut-mark data. Journal of Human Evolution 33, 669-690.

Domínguez-Rodrigo, M., Barba Egido, R., Egeland, C.P., 2007. Deconstructing Olduvai a taphonomic study of the Bed 1 sites. Springer, Dordrecht, Netherlands.

Domínguez-Rodrigo, M., Bunn, H.T., Mabulla, A.Z.P., Ashley, G.M., Diez-Martin, F., Barboni, D., Prendergast, M.E., Yravedra, J., Barba, R., Sánchez, A., Baquedano, E., Pickering, T.R., 2010a. New excavations at the FLK Zinjanthropus site and its surrounding landscape and their behavioral implications. Quaternary Research 74, 315332. doi:10.1016/j.yqres.2010.07.003

Domínguez-Rodrigo, M., Mabulla, A.Z.P., Bunn, H.T., Diez-Martin, F., Baquedano, E., Barboni, D., Barba, R., Domínguez-Solera, S., Sánchez, P., Ashley, G.M., Yravedra, J., 2010b. Disentangling hominin and carnivore activities near a spring at FLK North (Olduvai Gorge, Tanzania). Quaternary Research 74, 363-375. doi:10.1016/j.yqres.2010.07.004

Domínguez-Rodrigo, M., Pickering, T.R., 2003. Early hominid hunting and scavenging: A zooarcheological review. Evolutionary Anthropology: Issues, News, and Reviews 12, 275-282. doi:10.1002/evan.10119

Domínguez-Rodrigo, M., Pickering, T.R., Almécija, S., Heaton, J.L., Baquedano, E., Mabulla, A., Uribelarrea, D., 2015. Earliest modern human-like hand bone from a new \&gt;1.84-million-year-old site at Olduvai in Tanzania. Nature Communications 6, 7987. doi:10.1038/ncomms 8987 
Driese, S.G., Ashley, G.M., 2015. Paleoenvironmental reconstruction of a paleosol catena, the Zinj archeological level, Olduvai Gorge, Tanzania. Quaternary Research. doi:10.1016/j.yqres.2015.10.007

Eichhorn, B., Neumann, K., Garnier, A., 2010. Seed phytoliths in West African Commelinaceae and their potential for palaeoecological studies. Palaeogeography, Palaeoclimatology, Palaeoecology 298, 300-310. doi:10.1016/j.palaeo.2010.10.004

Fraysse, F., Pokrovsky, O.S., Schott, J., Meunier, J.-D., 2006. Surface properties, solubility and dissolution kinetics of bamboo phytoliths. Geochimica et Cosmochimica Acta 70, 1939-1951. doi:10.1016/j.gca.2005.12.025

Garnier, A., Neumann, K., Eichhorn, B., Lespez, L., 2012. Phytolith taphonomy in the middle-to late-Holocene fluvial sediments of Ounjougou (Mali, West Africa). The Holocene 959683612463102.

Hay, R.L., 1971. Geologic background of Beds I and II, in: Olduvai Gorge. Cambridge University Press, London, pp. 9-18.

Hay, R.L., 1976. Geology of the Olduvai Gorge: A Study of Sedimentation in a Semiarid Basin. University of California Press.

Kamau, P.W., 2012. Systematic revision of Pteris L. in tropical Africa and ecology of ferns and lycophytes in lowland tropical rainforests. Universität Koblenz-Landau.

Leakey, L.S., Tobias, P.V., Napier, J.R., 1964. A New Species of Genus Homo from Olduvai Gorge. Nature 202, 7-9.

Leakey, L.S.B., 1959. A new fossil skull from Olduvai. Nature 184, 491-493.

Leakey, M.D., 1971. Olduvai Gorge Volume 3. Excavations in Beds I and II, 1960-1963. Cambridge University Press, Cambridge.

Liutkus, C.M., Ashley, G.M., 2003. Facies model of a semiarid freshwater wetland, Olduvai Gorge, Tanzania. Journal of Sedimentary Research 73, 691-705.

Madella, M., Alexandre, A., Ball, T., 2005. International Code for Phytolith Nomenclature 1.0. Annals of Botany 96, 253-260. doi:10.1093/aob/mci172

Magill, C.R., Ashley, G.M., Freeman, K.H., 2013a. Ecosystem variability and early human habitats in eastern Africa. Proceedings of the National Academy of Sciences 110, 1167-1174. doi:10.1073/pnas.1206276110
Magill, C.R., Ashley, G.M., Freeman, K.H., 2013b. Water, plants, and early human habitats in eastern Africa. Proceedings of the National Academy of Sciences 110, 1175-1180. doi:10.1073/pnas. 1209405109

Magill, C.R., Ashley, G.M., DomínguezRodrigo, M., Freeman, K.H., 2016. Dietary options and behavior suggested by plant biomarker evidence in an early human habitat. Proceedings of the National Academy of Sciences 113, 2874-2879. doi:10.1073/pnas.1507055113

Mercader, J., Astudillo, F., Barkworth, M., Bennett, T., Esselmont, C., Kinyanjui, R., Grossman, D.L., Simpson, S., Walde, D., 2010. Poaceae phytoliths from the Niassa Rift, Mozambique. Journal of Archaeological Science 37, 1953-1967. doi:10.1016/j.jas.2010.03.001

Mercader, J., Bennett, T., Esselmont, C., Simpson, S., Walde, D., 2009. Phytoliths in woody plants from the Miombo woodlands of Mozambique. Annals of Botany 104, 91113. doi:10.1093/aob/mcp097

Novello, A., Barboni, D., Berti-Equille, L., Mazur, J.-C., Poilecot, P., Vignaud, P., 2012. Phytolith signal of aquatic plants and soils in Chad, Central Africa. Review of Palaeobotany and Palynology 178, 43-58. doi:10.1016/j.revpalbo.2012.03.010

Oliver, J.S., 1994. Estimates of hominid and carnivore involvement in the $\{\mathrm{FLK}\}$ Zinjanthropus fossil assemblage: some socioecological implications. Journal of Human Evolution 27, 267-294. doi:http://dx.doi.org/10.1006/jhev.1994.104 6

Pickering, T.R., Domínguez- Rodrigo, M., 2006. The acquisition and use of large mammal carcasses by Oldowan hominins in eastern and southern Africa: a selected review and assessment, in: Schick, K.D., Toth, N.P. (Eds.), The Oldowan: Case Studies into the Earliest Stone Age, Stone Age Institute Publication Series. Stone Age Institute, Gosport, IN, pp. 113-128.

Rose, L., Marshall, F., 1996. Meat Eating, Hominid Sociality, and Home Bases Revisited. Current Anthropology 37, 307338.

Rossouw, L., 2009. The application of fossil grass phytolith analysis in the reconstruction of late Ceinozoic environments in the South African interior. University of the Free State, Bloemfontein 
South Africa.

Rossouw, L., Scott, L., 2011. phytoliths and pollen, the microscopic plant remains in Pliocene volcanic sediments around Laetoli, Tanzania, in: Harrison, T. (Ed.), Paleontology and Geology of Laetoli: Human Evolution in Context. Volume 1: Geology, Geochronology, Paleoecology and Paleoenvironment. Springer Science+Business Media B.V., Dordrecht.

Runge, F., 1999. The opal phytolith inventory of soils in central Africa - quantities, shapes, classification, and spectra. Review of Palaeobotany and Palynology 107, 2353.

Stromberg, C., 2004. Using phytolith assemblages to reconstruct the origin and spread of grass-dominated habitats in the great plains of North America during the late Eocene to early Miocene. Palaeogeography, Palaeoclimatology, Palaeoecology 207, 239-275. doi:10.1016/j.palaeo.2003.09.028

Stromberg, C., 2003. The origin and spread of grass-dominated ecosystems during the Tertiary of North America and how it relates to the evolution of hypsodonty in equids. University of California, Berkeley.

Stromberg, C., 2002. The origin and spread of grass-dominated ecosystems in the late Tertiary of North America: preliminary results concerning the evolution of hypsodonty. Palaeogeography, Palaeoclimatology, Palaeoecology 177, 5975.

Strömberg, C.A.E., 2009. Methodological concerns for analysis of phytolith assemblages: Does count size matter? Quaternary International 193, 124-140. doi:10.1016/j.quaint.2007.11.008

Tobias, P.V., 1991. Olduvai Gorge: The Skulls, Endocasts and Teeth of Homo habilis. Cambridge University Press, Cambridge.

Tschernich, R.W., 1992. Zeolites of the World. Geoscience Press. pp.602.

Uribelarrea, D., Domínguez-Rodrigo, M., Pérez-González, A., Vegas Salamanca, J., Baquedano, E., Mabulla, A., Musiba, C., Barboni, D., Cobo-Sánchez, L., 2014. Geoarchaeological and geometrically corrected reconstruction of the 1.84 Ma FLK Zinj paleolandscape at Olduvai Gorge, Tanzania. Quaternary International 322-323, 7-31. doi:10.1016/j.quaint.2013.12.023

\section{CAPTIONS}

Figure 1. Location of Olduvai Gorge, Tanzania. (A) Position of Olduvai Gorge in East Africa. (B) Close-up on the Crater Highlands region (map from NASA's Earth Observatory website). (C) Position of the paleosol samples from Zinj complex in the junction area (map from Google Earth). Red circles: samples analyzed in this study, green squares: Ashley et al. (2010a), stars: tufa position.

Figure 2. Stratigraphy and lithology of the lower-middle Bed I in the junction area, Olduvai Gorge. (A) Schematic type section with the main units described from the basalt to Tuff IC (modified from Uribelarrea et al., 2014). CHT: Chapati tuff. The "Zinj clay" unit is typically waxy Vertisols clay with vertic (shrink-swell) features, but in localized areas the clay is described as siliceous earthy. Examples of well-marked facies changes within the Zinj clay unit in PTK area: (B) lateral and vertical facies changes at PTK Trench 10/2013 with position of the soil profiles A (in waxy vertisol clay) and B (in siliceous earthy clay) studied by Driese and Ashley (2015), (C) other example of lateral facies changes at PTK Trench 22/2014.

Figure 3. Examples of phytoliths from FLK Zinj samples. Grass silica short cells A-B, A: Rondel cylindrical short/tabular, base round/oblong; B: Bilobate concave lobes; C: Parallelepipedal. Faceted, sharp edges; D: Parallelepiped body, bulliform-type texture; E: Globular granulate irregular body (multiple globules) typical of the Forest Indicator category; F: Elongate tabular or slightly cylindrical, surface perforated-granulated; G: Hexagonal-round platelet with rounded apex "hat-shaped" typical of sedges (Cyperaceae); $\mathrm{H}$ : Globular echinate body with distinct spines typical of Palms (Arecaceae).

Figure 4. Relative abundance of the phytolith main morphotypes (in percent) in the Zinj paleosurface underlying Tuff IC (1.84 Ma), Olduvai Gorge, Tanzania.

Figure 5. Relative abundance of phytoliths grouped by botanical attribution shown here as pie diagrams placed according to the geographic position of the samples collected in 
the Gorge directly below Tuff IC. For clarity, averages are given for localities with several samples (FLK Zinj $n=5$, PTK $n=6$, and DS $n=$ $2)$. Grey shading represent modern topography and modern Olduvai River. Orange hashed area indicates potential spatial extent of the siliceous earthy clay facies underlying Tuff IC.

Figure 6. Relative abundance of phytoliths grouped by botanical attribution shown here as pie diagrams placed according to the stratigraphic position for samples collected vertically below Tuff IC (1.84 Ma).

Figure 7. SEM and optical micrographs of zeolites and zeolitized phytoliths. A) zeolitized phytoliths with crystals growing on a trapeziform sinuate phytolith, B) zeolite showing echines and ridges under optical microscope, C) zeolite (chabazite) crystals inter-growing and looking like druses under optical microscope, D) zeolite crystals growing on -globular granulate phytoliths, E) zeolite (clinoptilolite) crystals resembling trapeziform short cells but not the secondary crystal growing on the side, F) zeolite (philipsite) with parallelepipedal and elongate shapes, G) zeolite (clinoptilolite) crystals growing as imbricated cubes.

Figure 8. Correlation between the relative abundance of zeolites (in percent over the sum of phytoliths plus zeolites) and the relative abundances of diagnostic phytoliths (top) and of unidentified, damaged, and dubious phytoliths (below), according to lithology (waxy-vertisol-clay versus siliceous earthyspring-clay), as recorded for the 37 samples from the Zinj paleosurface underlying Tuff IC.

Table 1. List of Zinj Complex paleosol samples underlying Tuff IC.

Appendix A. Detailed phytolith counts in "Zinj complex" sites samples collected under Tuff IC. 

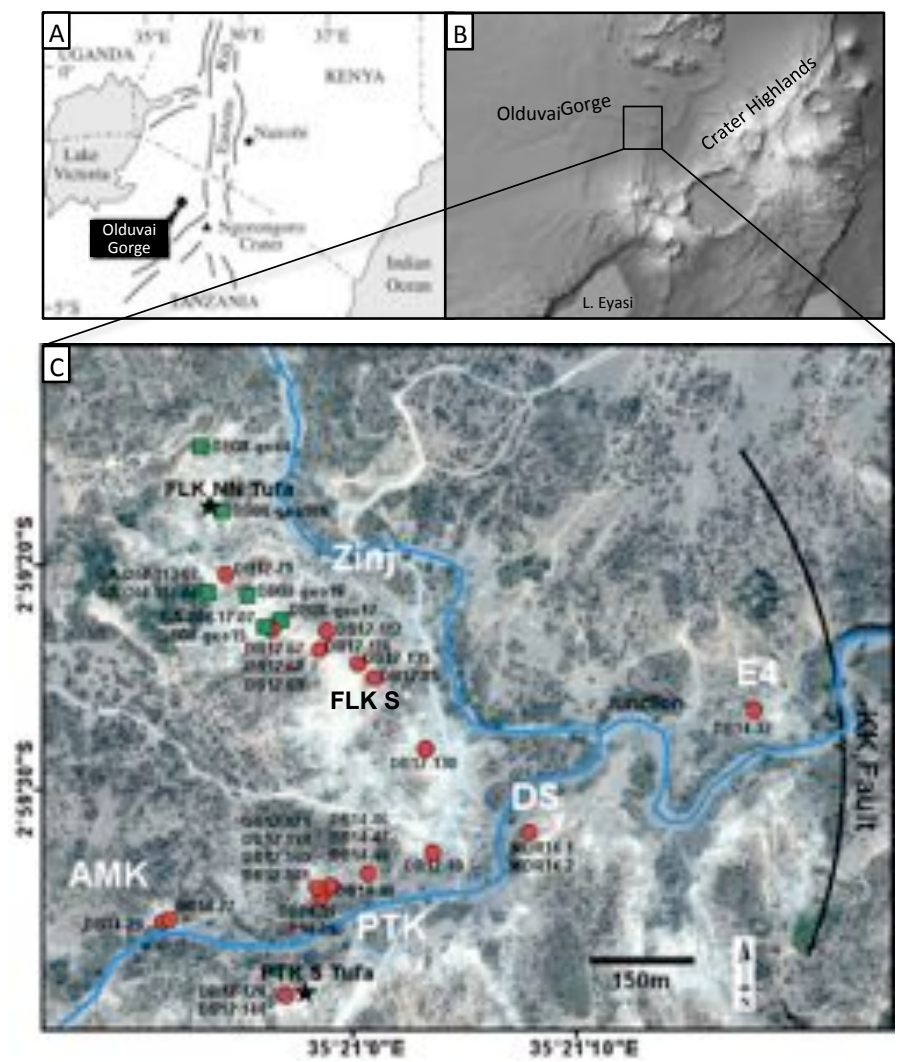

Figure 1

Arraiz et al.

March 2017 

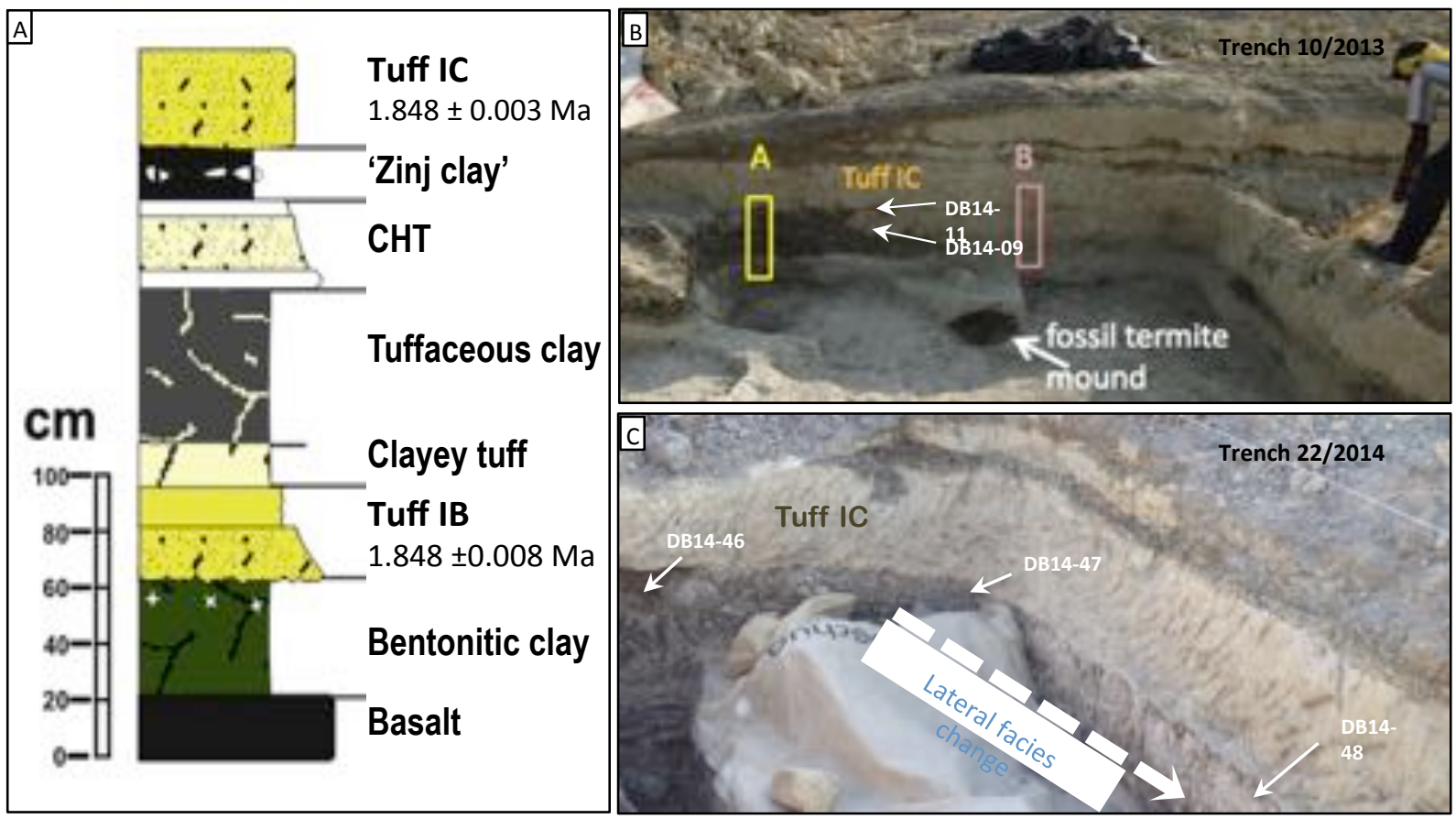

Tuff IC

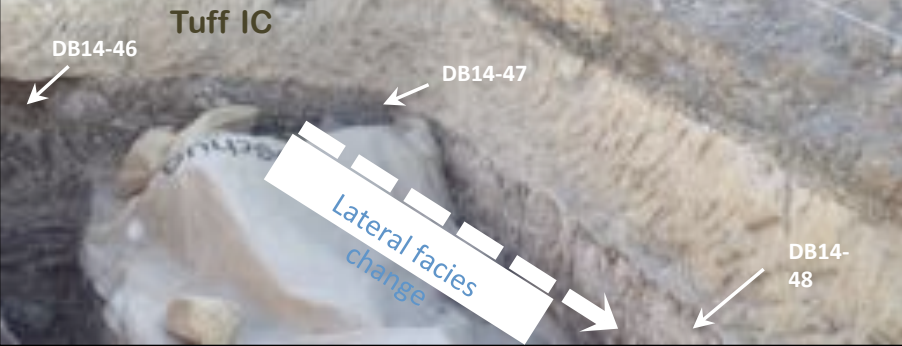

Figure 2

Arraiz et al.

Fev 2017 


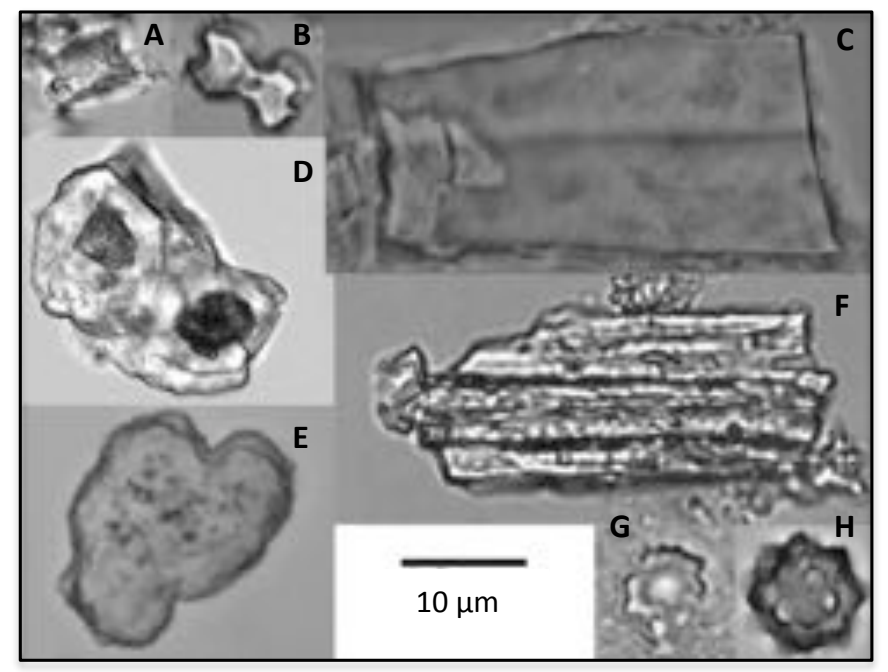

Figure 3

Arraiz et al.

Fev 2017 
Zeolites (\% over $\Sigma$

Phytoliths + zeolites)

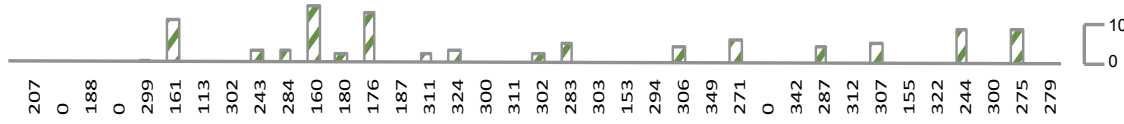

Non
Diagnostic

$\Sigma$ Phytoliths

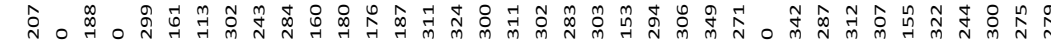

Unid/Damaged/

Dubious

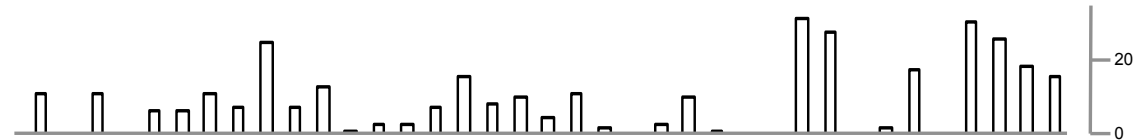

Miscellianous

ND

Ferns

Sedges

Grasses

Blocky facetted

Platelets (hat-)

Bulliforms

Lobate

Rondel, Saddle

Trapeziform sc

Pyramidal

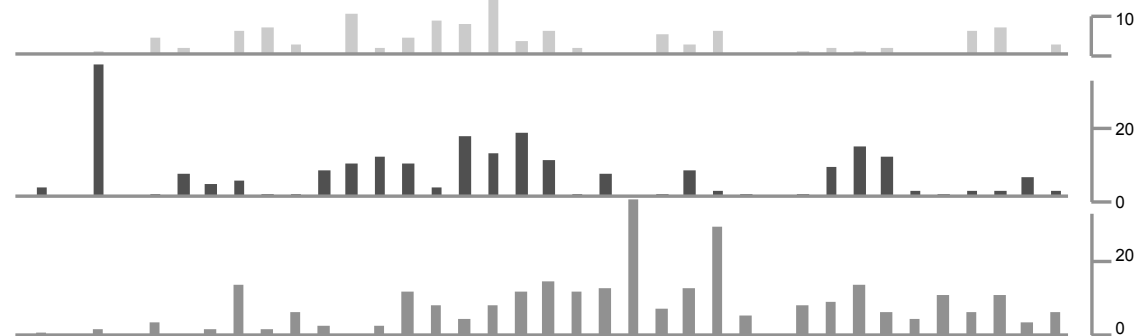

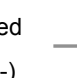

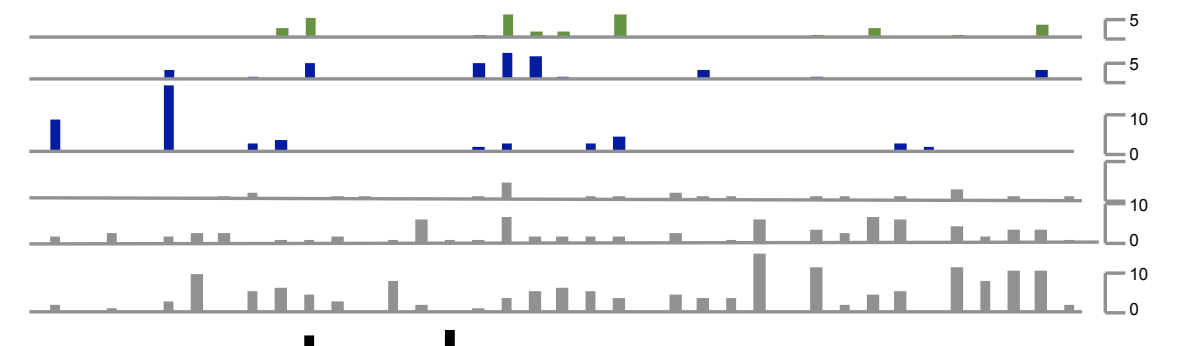

Misc. FI (Blocky,

Plates, Silicified

tissues)

Sclereids

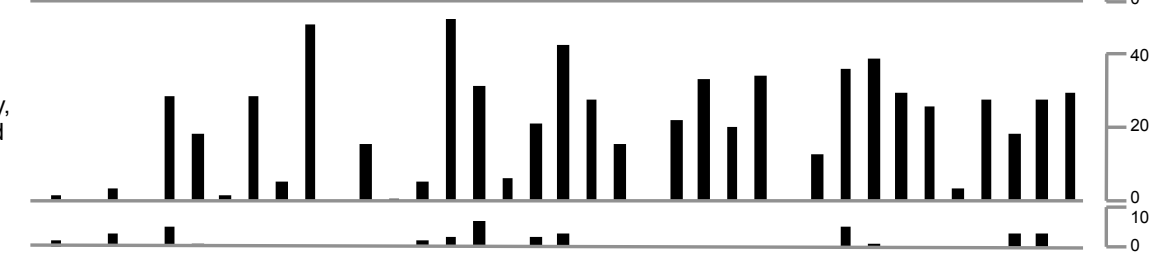
Forest
Indicators
Forest
Indicators

Figure 4

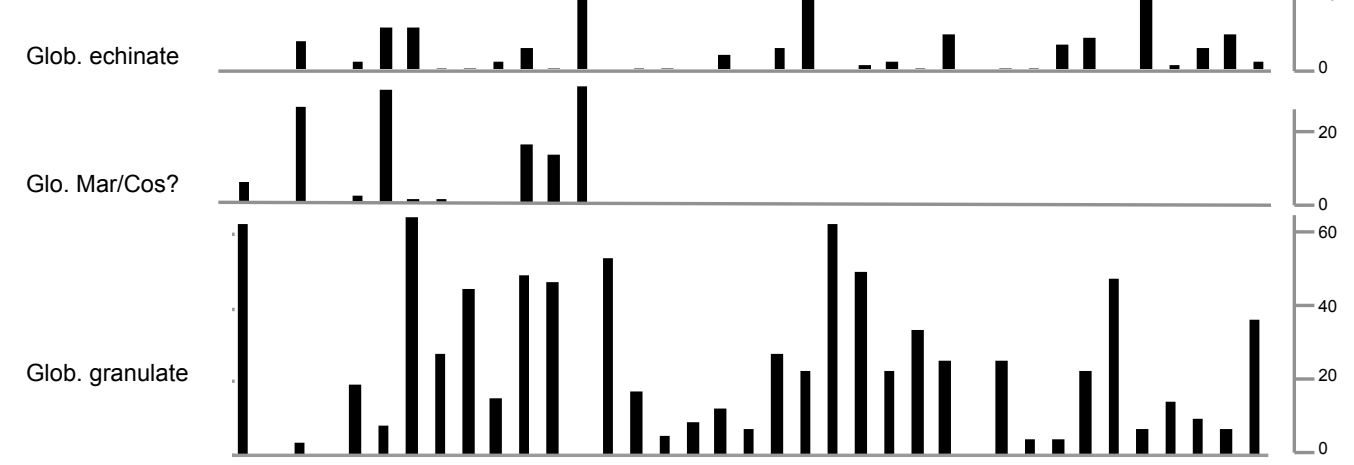

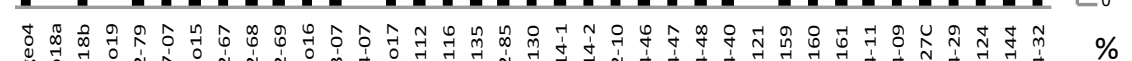

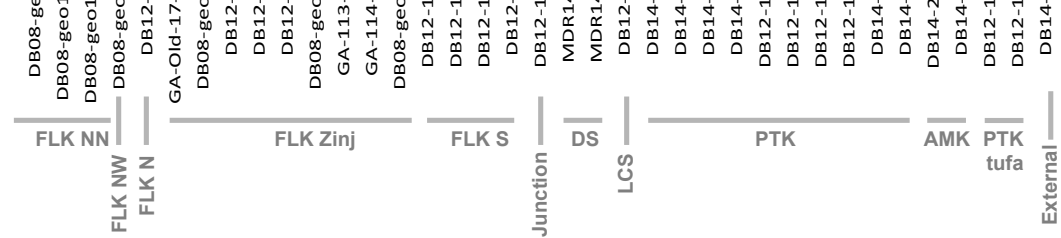

Arraiz et al.

Fev 2017 


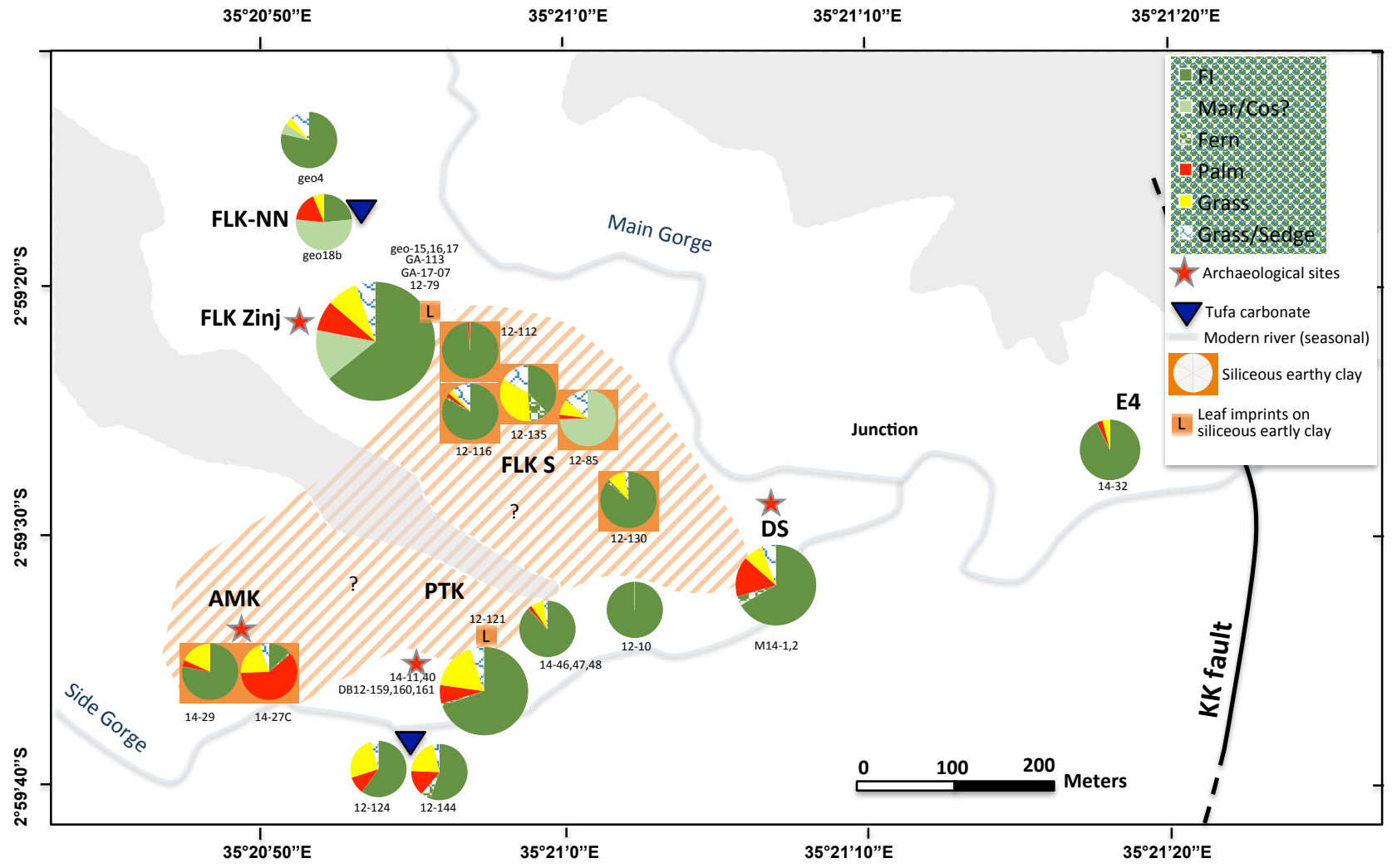

Figure 5

Arraiz et al.

Fev 2017 


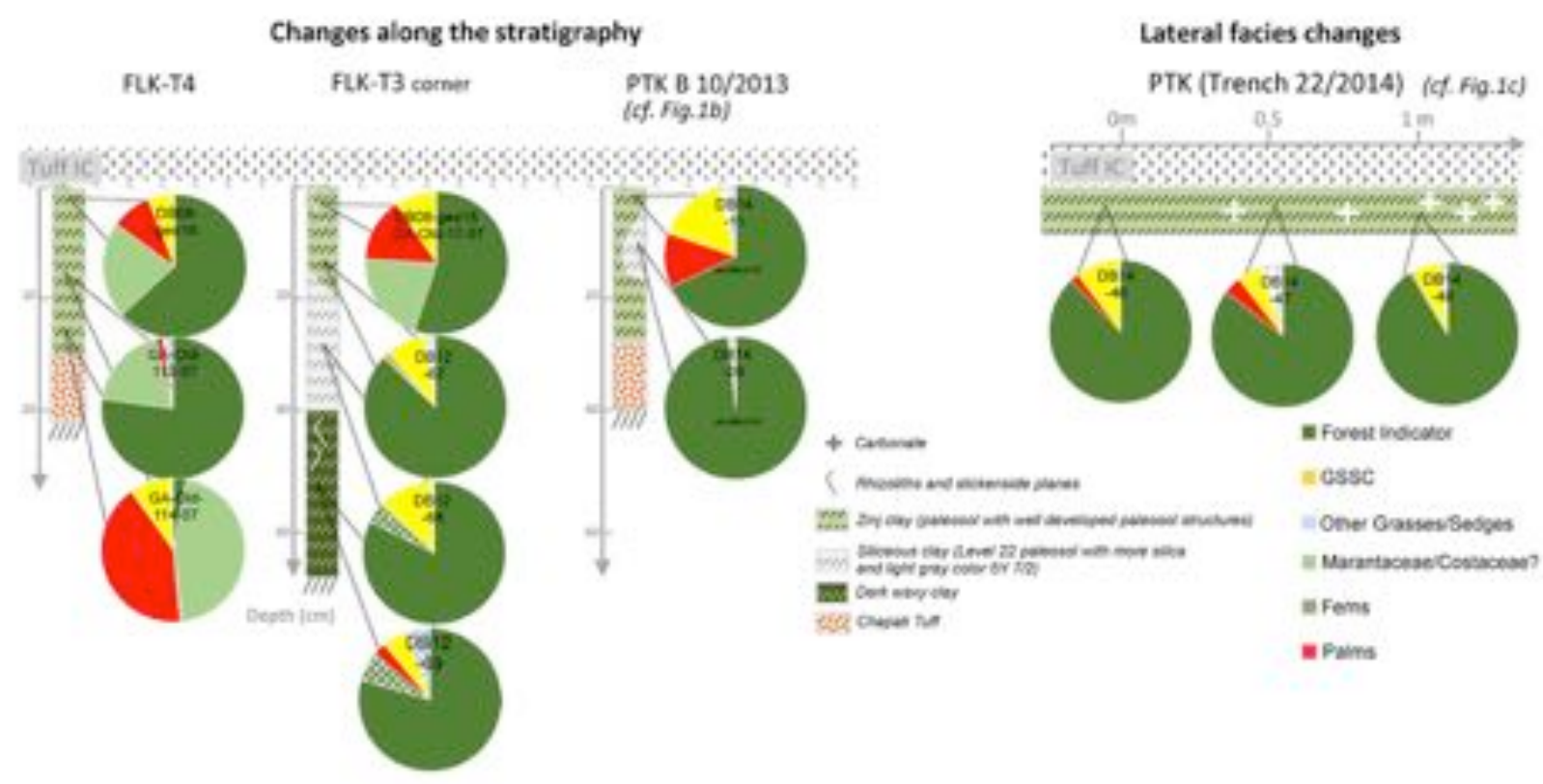

\section{Figure 6}

Arraiz et al.

Fev 2017 

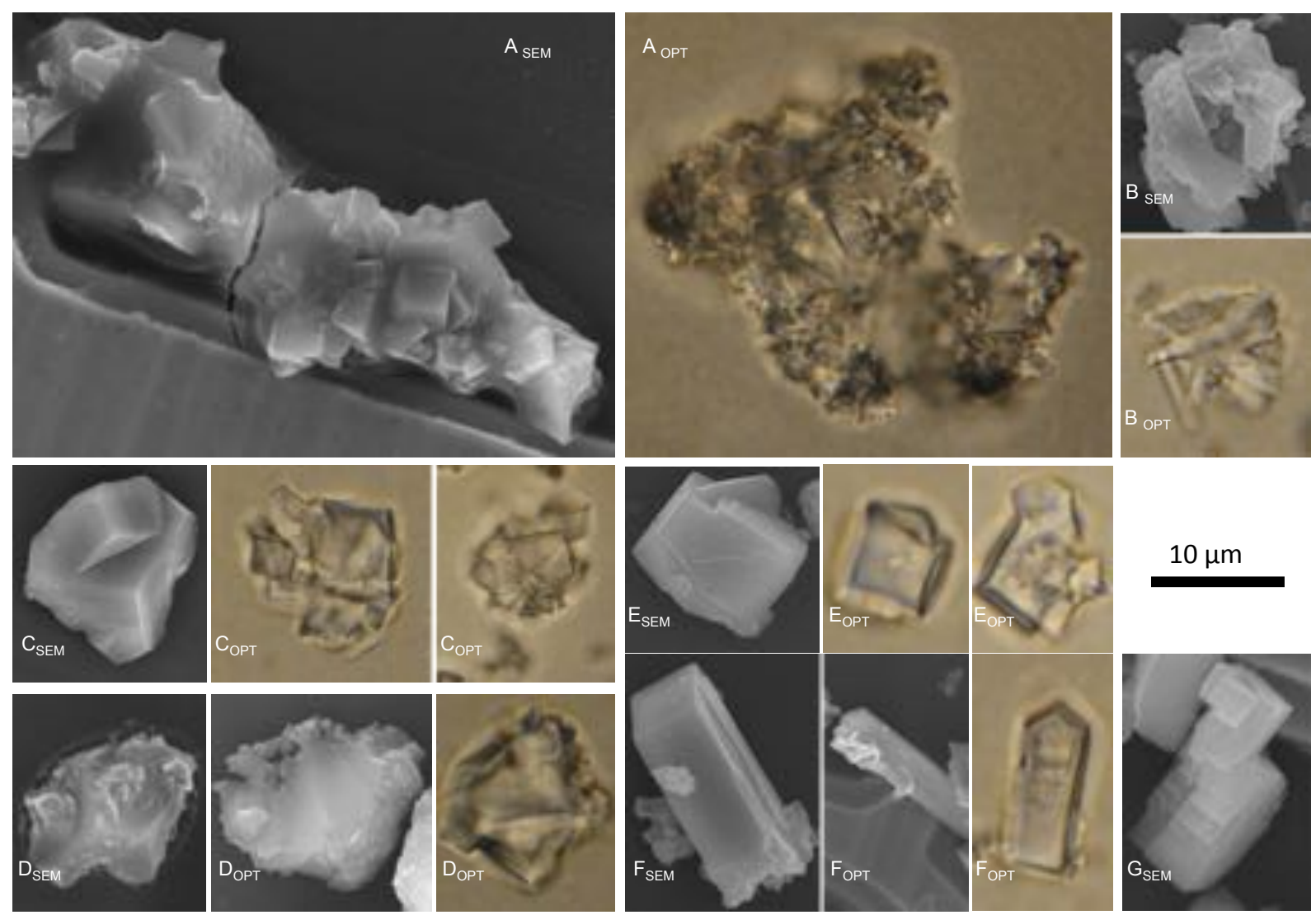

$B$ OPT

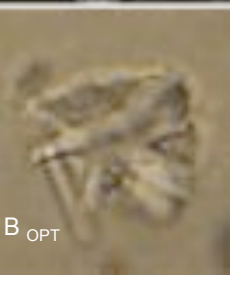

$10 \mu \mathrm{m}$

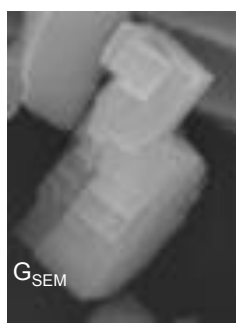

Figure 7

Arraiz et al.

Fev 2017 
- Siliceous Waxy
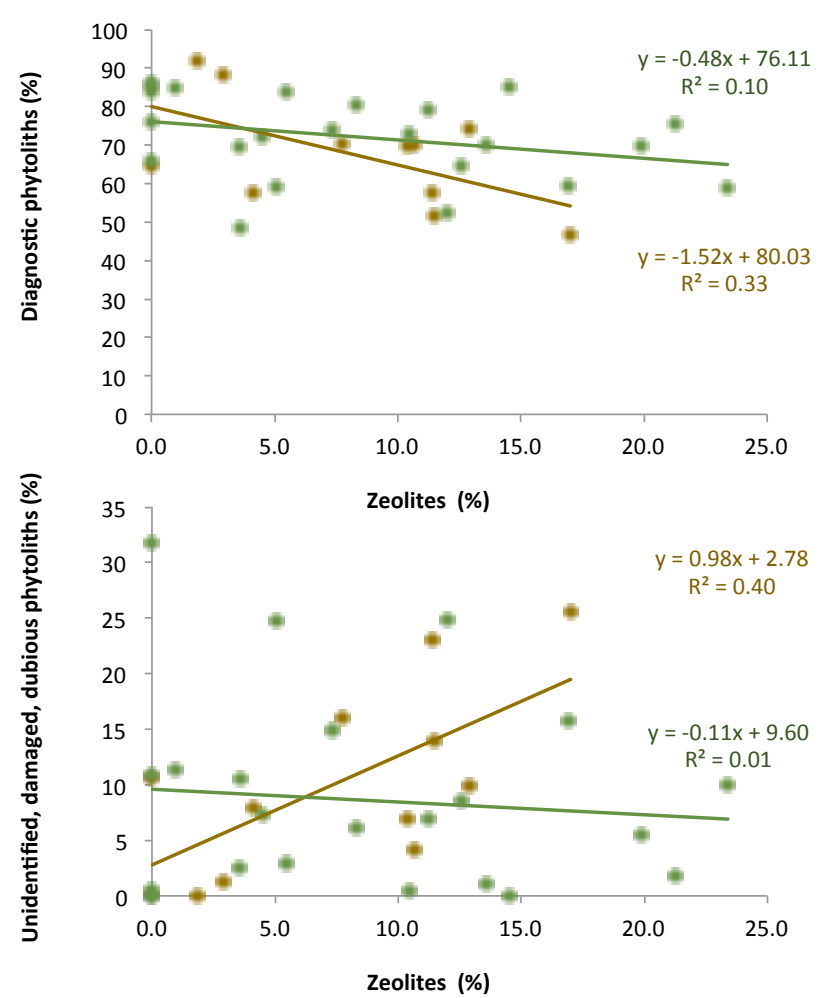

Figure 8

Arraiz et al.

Fev 2017 